\title{
Performance Management and Employee Engagement in Public Institutions: A Developing Country Perspective
}

\author{
Benjamin Otchere-Ankrah, PhD \\ Department of Management and Public Administration, \\ Central University, Accra, Ghana \\ Miotso near Dawhenya. \\ Off the Accra - Aflao Road, Ghana
}

Received: Nov. 8, 2021 Accepted: Feb. 23, 2022 Online published: Mar. 1, 2022

doi:10.5296/ijhrs.v12i1.19146

URL: https://doi.org/10.5296/ijhrs.v12i1.19146

\begin{abstract}
The need to have the right talents and be engaged in driving the organization's vision is riper than ever. Given the importance of having engaged employees, this study examines how employee engagement affects performance and what drives employee engagement in public sector organisations. To answer these questions, a quantitative research approach was adopted. In all, 156 employees of PLTD participated. The results show a significant relationship between employee engagement at work and employee performance at PLTD. This means that the more employees are engaged with their work, the more they perform well on the job. This implies that productivity increases when organizations motivate their employees to be highly engaged in their work. This result implies that the more engaged employees are, the better their contribution to organizational success. These results have implications for theory and practice.
\end{abstract}

Keywords: developing, employee engagement, performance management, public institutions

\section{Introduction}

Having the right talents strategically contributes to several aspects of the organization, such as innovation and commitment to the work (Ashton \& Morton, 2005). Therefore, organizations need to develop the ability to attract, engage and retain talents to gain a competitive advantage. Failure to achieve this may result in the organization losing its talents, ultimately affecting its competitive advantage. In this situation, engaged employees may be a key to competitive advantage. Studies have confirmed that engaged employees have high 
energy levels and are very enthusiastic about their job (May, Gilson \& Harter, 2004). Conditions that enhance employee engagement in most organizations constitute a competitive advantage for firms, making it very difficult to imitate. In recent times, employee engagement has become a critical organisational issue drawing attention from both theory and practice (Saks, 2006). It has attracted the attention of organizations, professional societies, and consulting companies. This is seemingly as attractive for organizations for professional societies and consulting groups. It is argued that organizations with an engaged workforce stand to achieve the following: high levels of productivity, profitability, efficiency, low turnover, and high probability of engaging in discretionary efforts (Buchanan, 2004).

This partly explains why several corporate executives pay much attention to or prioritize employee engagement (Katter, 2008). Engagement can potentially affect employee retention, productivity, and loyalty significantly. While acknowledging the progress made in the literature concerning employee engagement, this study provides insights from the Ghanaian public sector, where little is known. Employee engagement has received significant research attention (Kim et al., 2012; Rurkkhum \& Bartlett, 2012; Simpson, 2009; Shuck \& Wollard, 2011). Employee engagement is recognized as a predictor of employee performance in public or private organizations (Saks, 2006; Macey \& Schneider, 2008). Studies have recently revealed that disengaged employees outnumber engaged employees, implying that employee performance is in danger. For example, studies by Gallup (2013) and Robertson and Cooper (2010) have found low levels of employee engagement in several countries. These studies suggest that only $13 \%$ of employees are engaged. In countries such as the United States of America and China, 52\% and 68\%, respectively, are disengaged. Unlike disengaged employees, engaged employees are energetic and more connected to the job and therefore feel about achieving organizational objectives (Schaufeli et al., 2008). Employee engagement has been found to have a positive effect on organisational outcomes. This is mainly driven by the employee's level of satisfaction and motivation (Alfes et al., 2010; Bakker and Xanthopoulou, 2009). Despite the above assertion, there is the possibility that employees may be satisfied in organisations that poorly perform, which implies that satisfaction and motivational levels of employees may not necessarily lead to engagement, which enhances employee performance. In light of the above discussions, it is evident that the relationship has gained immense attention amongst scholars in human resource development. However, these studies tend to focus on private sector organisations in developed countries (Alfes et al., 2010; Bakker \& Xanthopoulou, 2009; Kim et al., 2012; Rurkkhum \& Bartlett, 2012; Simpson, 2009; Shuck \& Wollard, 2011) and therefore its application in the public sector remains a crucial challenge for most developing nations (Sanneh \& Taj, 2015). Although much has been written on the influence of employee engagement on performance management, very little has been done in the area of the public sector of Ghana (Agyemang \& Ofei, 2013). This study seeks to contribute to research in workforce management vis-a-vis the impact of employee engagement on performance management drawing on the workforce of PLtd.

\section{Literature Review}

Employee Performance Management 
Performance management (PM) is traditionally defined as the systematic application of processes to optimize the performance of individuals in organizations (Warren, 1982). It is also defined as a "systematic process for improving organizational performance by developing the performance of individuals and teams" (Armstrong, 2006, p. 1). While the ultimate objective of performance management systems is to enhance the performance of individuals to drive the performance of the entire organization, there is a widespread failure in PM achieving such objectives. Several reasons have been assigned to this failure which includes but are not limited to the administrative burden on managers/supervisors and employees, poor communication or absence of candid performance review, delays in providing feedback as well as rating biases (Pulakos \& O'Leary, 2011; Pulakos, Mueller-Hanson \& O'Leary, 2008; Watson, 2004). For example, the study by Watson (2004) found that only one-third of workers believe that the PM system adopted by their organizations has impacted their performance. Additionally, less than half of the employees (i.e., 1190 workers) who participated in the study have a PM system with clear and consistent goals, generates honest feedback, and is technologically advanced.

The findings from Watson's (2004) study draws our attention to the need to automate PM systems to improve systems' ability to recognize top performers while helping poor performers to improve their performance. Such systems will conform to the suggestions provided by the researchers from Watson Wyatt Worldwide. They believe that a well-thought-out and structured PM system can improve individual performance and ultimately improve the organization's. In addition to these practical implications, several theoretical issues remain that require contemporary scholars' attention. For example, Buchner (2007) questions whether the PM systems used by organizations have theoretical support.

Buchner (2007) further argues that a more relevant theoretical framework for the design and study of PM is goal-setting theory. The goal-setting theory argues that goals are linked to the performance of tasks. It states when goals are challenging and supported by appropriate feedback, they drive better performance of tasks among employees. Goals affect the performance of individuals in several ways: (1) how complex or specific the goal is, (2) direction and attention required, (3) the efforts and persistence, and (4) the development of strategy (Locke \& Latham, 2002). While this is the ideal situation, there have been several questions as to whether or not the goals of most PM systems are achievable (Buchner, 2007). A related theory is the control theory which describes the ongoing comparative processes of reducing the differences in standards and actual behaviors of individuals to achieve the goals of PM systems (Carver \& Scheier, 1998). The feedback can shape the behaviors of individuals received or provided in the process (Buchner, 2007). However, feedback in the workplace is generally insufficient (Fletcher, 2001).

\section{Employee Engagement and Performance Management}

According to Kahn (1990), engagement affects employee performance. In her research of six public organizations, Sonnentag (2003) found that a high level of engagement helps employees "in taking the initiative and pursuing learning goals" (p.525). Engaged employees do not hold back; they exert more energy and are enthusiastically committed to the work they 
do. Engaged employees go beyond the job description; they dynamically change and arrange their job in a way in which it fits the changing work environment (Bakker \& Leiter, 2010). Engaged employees see meaningfulness in their work (Maslach et al., 2001; Perrin 2003). Salanova, Agut \& Peiro (2005), on the other hand, argued that engaged work-groups perform better by complementing each other to achieve results based on the collective efforts of the individuals in the group.

\section{Methodology}

Research design is defined as a blueprint for conducting a study with maximum control over factors that may interfere with the findings (Burns \& Grove, 2003). To examine the impact of employee engagement on performance management within the workforce of PLTD, the experimental research design was adopted for this study. This research design was chosen because the researcher wants to examine the issues arising from engagement at work and employee performance. Quantitative statistics focusing on the impacts of employee engagement on employee performance management will be employed.

The population for the study included all employees working at PLtd. The participants were working in a wide variety of different roles and locations. For accessibility, a random sample was taken from the population ranging from having managerial roles to subordinate workers. The sample for the study included full-time employees. Thus those who were on leave were excluded from this study. In all, one-hundred and fifty (156) employees participated in the study. The average age of the respondents was between the ages of $18-59$ years, with an average length of working life in the company between five (5) to twenty (20) years and over. The respondents for this study were conveniently sampled. Convenience sampling is a non-probability sampling technique based on the researcher's judgment. The subjects were selected because it was more convenient to reach out to them for this study. Convenience or opportunity sampling is a type of sampling where the only criterion is the researcher's convenience.

The study comprised two significant variables: employee engagement, which is the independent variable, and employee performance, which is the dependent variable. Respondents' engagement at work was operationalized by asking respondents based on the three central dimensions of engagement, namely, engagement at work, social engagement, and intellectual engagement, to indicate on a five-point scale how frequently they were engaged in their work with item scale adopted from Gallup. Scoring was done based on the Likert scale, where scores ranging from 1 to 5 were assigned to the responses to items on the instrument.

There are two main types of data: primary and secondary data used for this study. The primary sources consisted of unpublished data and observations gathered from the people in the organization, which included questionnaires. On the other hand, secondary sources refer to materials, books, articles, and journals that have been previously published through the internet and other social media. All quantitative data were entered into the Statistical Package for Social Sciences (SPSS) software (version 20.0 for Windows) and examined for statistically significant relationships using regression analysis. 


\section{Results}

The relationships were tested through a regression analysis which looked at the relationship between engagement at work, social engagement, intellectual engagement, and employee performance. The results of the three hypotheses were tested using inferential statistics and correlations. The hypotheses formulated were tested using descriptive statistics and regression analysis. The descriptive statistics are presented in Table 1 below

Table 1. Descriptive Statistics

\begin{tabular}{lcc}
\hline Job satisfaction & Mean & SD \\
\hline Employee performance & 3.98 & 0.81 \\
Engagement at work & 4.02 & 0.99 \\
Intellectual engagement & 4.13 & 1.01 \\
Social engagement & 3.79 & 0.88 \\
\hline
\end{tabular}

Source: Field data, 2020

Hypothesis one: There is a significant relationship between employee engagement at work and employee performance factors influencing employee engagement at PLtd.

Table 2. Summary of the relationship between employee engagement at work and Employee Performance at PLtd

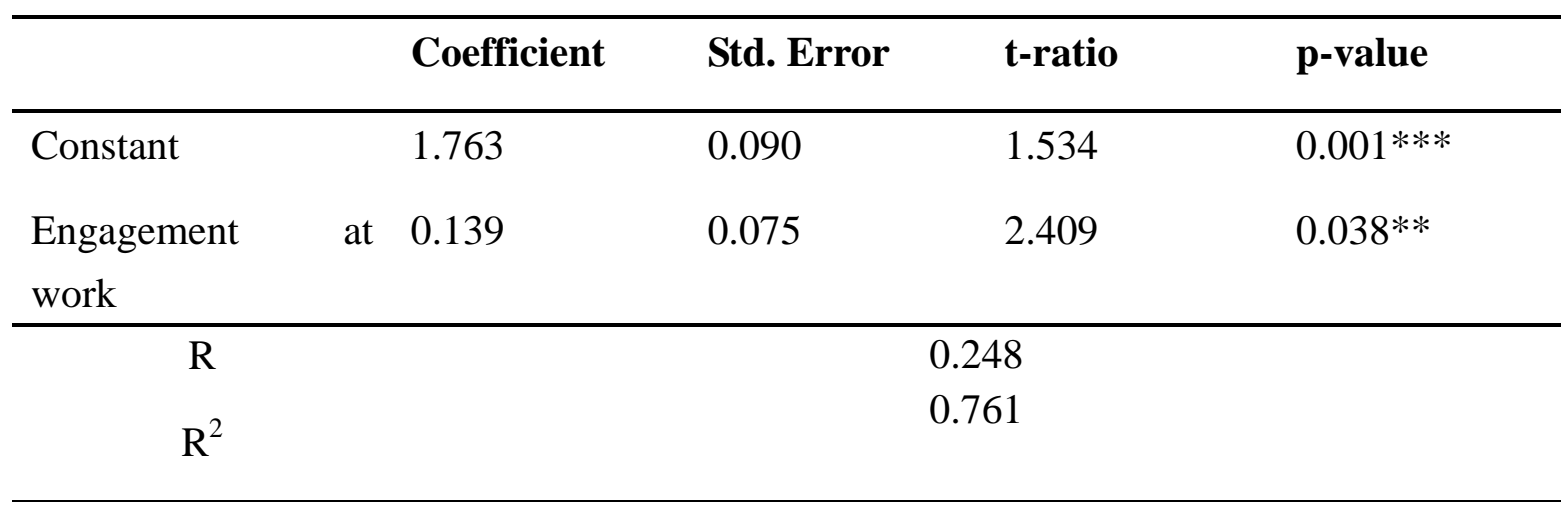

Source: Field data, $2020 * P<.01 * * *,<.05^{* *},<.10^{*}$,

Table 2 above presents the regression analysis results, which examined the relationship between employee engagement and employee performance at PLtd. Table 2 revealed a significant relationship between employee engagement and performance at PLtd. (0.139**). The table above indicates a weak correlation between engagement at work and employee performance. However, there is a significant relationship between the two variables. Therefore, the first hypothesis that "there is a significant relationship between employee engagement at work and employee performance" was supported. This means that the more employees are engaged in their work, the more they perform well on the job. 
Engaged employees often work harder, are more loyal, and commit to putting up extra efforts to achieve their organization's goals. Employee engagement can be examined from cognitive, emotional, and behavioral perspectives. While cognitive engagement focuses on employees' beliefs regarding the organization, its leaders, and colleagues, emotional engagement deals with how employees feel about the organization, its leaders, and the overall workplace culture. On the other hand, behavioral engagement focuses on the value-added components of energy, brainpower, and extra time committed to its employees. Employees who are highly involved in their work processes such as conceiving, designing, and implementing workplace and process changes are more engaged. As highlighted in the literature, the link between high-involvement work practices and positive beliefs and attitudes associated with employee engagement and generating behaviors leading to enhanced performance is an essential driver for business success. The responses gathered are not too different from the literature position. Given the importance of employee engagement to organizations, combined with the deepening disengagement among workers today, a vital issue is how to promote employees' engagement. May, Gilson, and Harter (2004) noted that engagement is essential for managers to cultivate, given that disengagement, or alienation, is central to workers' lack of commitment and motivation.

Hypothesis two: There is a significant positive relationship between intellectual engagement and employee performance at PLtd.

Table 3. Summary of the relationship between intellectual engagement at work and Employee Performance at PLtd

\begin{tabular}{cllcl}
\hline & Coefficient & Std. Error & t-ratio & p-value \\
\hline Constant & 3.002 & 1.134 & 2.078 & $0.002 * * *$ \\
Intellectual & 0.934 & 0.099 & 3.800 & $0.000 * * *$ \\
Engagement & & & & \\
\hline \multicolumn{1}{c}{$\mathrm{R}$} & & 0.575 & \\
\multicolumn{1}{c}{$\mathrm{R}^{2}$} & & 0.623 & \\
\hline
\end{tabular}

Source: Field data, $2020 * P<.01^{* * *},<.05^{* *},<.10^{*}$,

Table 3 above presents the regression results which examined the relationship between intellectual engagement and employee performance at PLtd. The results show a significant relationship between intellectual engagement and employee performance. Thus the correlation between the two variables is strong. The analysis revealed a significant relationship between intellectual engagement and employee performance at PLtd (0.934***). Therefore, the second hypothesis, "There will be a significant correlation between intellectual engagement at work and employee performance," was supported. This means that when employees are intellectually engaged in their work, they perform well on the job. The responses above support the view of scholars such as Schaufeli and Salanova (2007) and Kahn (1990). For example, Schaufeli and Salanova (2007) suggest that intellectually engaged 
employees are energetically and effectively connected to their work. This can occur by investing one's "self" in work activities. In his work on intellectual and personal engagement, Kahn (1990) suggested that engagement involves "the harnessing of organizational members' selves to their work roles; in engagement, people employ and express themselves physically, cognitively, and emotionally during role performances" (p. 694). By contrast, disengagement involves an extrication of employees from work roles. This means that when employees are disengaged, they withdraw to defend themselves physically, cognitively, and emotionally and this is evident in the performance of their roles (Kahn, 1990).

Hypothesis three: There is a significant positive relationship between social engagement and employee performance at PLtd.

Table 4. Summary of the relationship between social engagement at work and Employee Performance at PLtd

\begin{tabular}{cllll}
\hline & Coefficient & Std. Error & t-ratio & p-value \\
\hline Constant & 1.543 & 0.390 & 1.992 & $0.016^{* *}$ \\
Social Engagement & 0.202 & 0.034 & 2.174 & $0.000^{* * *}$ \\
\hline $\mathrm{R}$ & & & 0.585 & \\
$\mathrm{R}^{2}$ & & & 0.701 & \\
\hline
\end{tabular}

Source: Field data, $2020 * P<.01^{* * *},<.05^{* *},<.10^{*}$,

Table 4 above presents the regression results which examined the relationship between social engagement and employee performance at PLtd. The analysis revealed a significant relationship between social engagement and employee performance at PLtd. (0.202***). There is a significant relationship between social engagement and employee performance and the correlation between the two variables' interest. Therefore, the third hypothesis that "there will be a significant correlation between social engagement and employee performance" was supported. This means that when employees are engaged socially in their work, it increases their job performance.

\section{Conclusions of the Study}

The following conclusions can be made based on the data analysis in this study. The study first finds a significant relationship between employee engagement and employee performance. This implies that high levels of employee engagement impacts employee retention, foster customer loyalty, and improve organizational performance (Lockwood, 2007). The study also confirms the assertion by Coffman and Gonzalez (2002) that employee engagement has a statistical relationship with productivity, profitability, employee retention, safety, and customer satisfaction. Second, when employees are intellectually engaged at work, their performance increases. This study also provides support for the findings of Kahn (1990) on the influence of engagement on employee performance. Finally, when employees are socially engaged in their work, their performance increases. The results support the assertion 
that employee engagement provides an excellent tool for achieving competitive advantage. People are one factor that cannot be duplicated or imitated by the competitors and is considered the most valuable asset if managed and appropriately engaged. The employee engagement findings have emphasized that this point is considered the most potent factoorganization's performance. Therefore, it can be concluded that employee engagement has a significant effect on employee performance, which implies that PLtd needs to consciously work at enhancing the engagement of employees to improve upon their performance eventually. Again, PLtd has to institute a comprehensive mentoring program for its employees. Providing individual attention to employees' personal and work-related problems by supervisors (mentors) improves the level of engagement. One-to-one sessions between employees and line managers allow greater discussion about roles and objectives. Mentors should be committed to providing upward mobility and support to an employee's professional career at one end and personal development at the other. In addition, Reward and Recognition should be consistent. As a process of employee involvement, rewards correlate to higher recognition of achievement, thereby increasing employee performance. Recognition and appreciation by the supervisor and peer group have a vast influence on the performance of employees.

\section{References}

Agyemang, C. B., \& Ofei, S. B. (2013). Employee work engagement and organizational commitment: A comparative study of private and public sector organizations in Ghana. European Journal of Business and Innovation Research, 1(4), 20-33.

Armstrong, M. (2006). Performance management: Key strategies and practical guidelines. London, UK: Kogan Page Limited.

Ashton, C., \& Morton, L. (2005). Managing Talent for Competitive Advantage, Strategic HR Review, 4(5), 28- 31. https://doi.org/10.1108/14754390580000819

Bakker, A. B., Hakanen, J. J., Demerouti, E., \& Xanthopoulou, D. (2007). Job resources boost work engagement, particularly when job demands are high, Journal of educational psychology, 99(2), 274. https://doi.org/10.1037/0022-0663.99.2.274

Bates, S. (2004). Getting engaged, H.R. Magazine, 49(2), 44-51.

Berger, L., \& Berger, D. (2004). The talent management handbook. McGraw Hill Companies. S.A.

Buchanan, L. (2004). The things they do for love. Harvard Business Review, 82(12), 19-20.

Buchner, T. W. (2007). Performance management theory: A look from the performer's perspective with implications for HRD. Human Resource Development International, 10, 59-73. https://doi.org/10.1080/13678860601170294

Budworth, M. H., \& Mann, S. L. (2011). Performance management: Where do we go from here? Human Resource Management Review, 21(2), 81-84. https://doi.org/10.1016/j.hrmr.2010.09.014 


\section{Macrothink}

International Journal of Human Resource Studies ISSN 2162-3058

Carver, C. S., \& Scheier, M. F. (1998). On the self-regulation of behaviour. Cambridge: Cambridge University Press.

Coffman, C., \& Gonzalez-Molina, G. (2002). Follow this path: How the world's greatest organizations drive growth by unleashing human potential. New York, NY: Warner Books, Inc.

Development Dimensions International (DDI) (2005). Whitepaper-Driving employee engagement. Credit Union National Association, Inc.

Fletcher, C. (2001). Performance appraisal and management: The developing research agenda, Journal of Occupational and Organizational Psychology, 74, 473-87. https://doi.org/10.1348/096317901167488

Frank, F. D., Finnegan, R. P., \& Taylor, C. R., (2004). The race for talent: retaining and engaging workers in the 21st century, Human Resource Planning, 27(3), 12-25.

Gruman, J. A., \& Saks, A. M. (2011). Performance management and employee engagement. Human Resource Management Review, 21, 123-136. https://doi.org/10.1016/j.hrmr.2010.09.004

Harter, J. K., Schmidt, F. L., \& Hayes, T. L. (2002). Business-unit-level relationship between employee satisfaction, employee engagement, and business outcomes: A meta-analysis. Journal of Applied Psychology, 87, 268-279.

Hartley, J., Jackson, D., Klandermans, B., \& Vuuren, T., (1995). Job Insecurity: Coping with Jobs at Risk. Sage: London.

Hewitt Associates LLC. (2005) Employee engagement. Retrieved October, 2015, from http://was4.hewitt.com/Hewitt/services/talent/sub talent/ee_engagement.htm

Kahn, W. A. (1990). Psychological conditions of personal engagement and disengagement at work. Academy of Management Journal, 33, 692-724. https://doi.org/10.5465/256287

Ketter, P. (2008). What's the big deal about employee engagement? Training \& Development, $62,44-49$.

Kompaso, S. M., \& Sridevi, M. S. (2010). Employee engagement: The key to improving performance. International Journal of Business and Management, 5(12), p89.

Locke, E. A., \& Latham, G. P. (2002). Building a practically useful theory of goal setting and task motivation: A 35-year odyssey. American Psychologist, 57, 705-717. https://doi.org/10.1037/0003-066X.57.9.705

Lockwood, N. R. (2007). Leveraging Employee Engagements for Competitive Advantage: H.R.s Strategic Role. HR Magazine, 52(3), 1-11.

Macey, W. H., (2006). Toward a definition of engagement. Paper presented at the Society for Industrial and Organizational Psychology 21st Annual Conference, May, Dallas, TX.

Macey, W., \& Schneider, B. (2008). The meaning of employee engagement. Industrial and 
Organizational Psychology, 1(1), 3-30. https://doi.org/10.1111/j.1754-9434.2007.0002.x

Maslach, C., Schaufelli, W. B., \& Leiter, M. P. (2001). 'Job burnout', Annual Review of Psychology, 52, 397-422. https://doi.org/10.1146/annurev.psych.52.1.397

Maslow, A. (1970). Motivation and personality (2nd Ed.). New York: Harper and Row.

May, D. R., Gilson, R. L., \& Harter, L. M. (2004). The psychological conditions of meaningfulness, safety and availability and the engagement of the human spirit at work, Journal of Occupational \& Organizational Psychology, 77(1), 11-37. https://doi.org/10.1348/096317904322915892

Mone, E. M., \& London, M. (2010). Employee engagement; through effective performance management. A practical guide for managers. Routledge Press. NY.

Perrin, T. (2003). Working Today: Understanding What Drives Employee Engagement. The 2003 Towers Perrin Talent Report U.S Report.

Pulakos, E. D., \& O'Leary, R. S. (2011). Why is performance management broken? Industrial and Organizational Psychology: Perspectives on Science and Practice, 4, 146-164. https://doi.org/10.1111/j.1754-9434.2011.01315.x

Rafferty, A. M., Maben, J., West, E., \& Robinson, D. (2005). What makes a good employer? Issue Paper 3 International Council of Nurses Geneva.

Resick, C. J., Baltes, B. B., \& Shantz, C. W. (2007). Person-organization fit and work-related attitudes and decisions: Examining interactive effects with job fit and conscientiousness. Journal of Applied Psychology, 92, 1446-1455. https://doi.org/10.1037/0021-9010.92.5.1446

Richman, A. (2006). 'Everyone wants an engaged workforce; how can you create it?' Work span, 49, 36-39.

Robinson, D., Perryman, S., \& Hayday, S. (2004). The Drivers of Employee Engagement. Brighton, Institute for Employment Studies.

Saks, A. M. (2006). Antecedents and consequences of employee engagement. Journal of managerial psychology, 21(7), 600-619. https://doi.org/10.1108/02683940610690169

Sanneh, L., \& Taj, S. A. (2015). Employee engagement in the public sector: a case study of Western Africa. International Journal of Human Resource Studies, 5(3), 70-101.

Schaufeli, W. B., \& Bakker, A. B. (2004). Job demands, job resources, and their relationship with burnout and engagement: A multi-sample study. Journal of organizational Behavior, 25(3), 293-315. https://doi.org/10.1002/job.248

Wollard, K. K., \& Shuck, B. (2011). Antecedents to employee engagement: A structured review of the literature. Advances in developing human resources, 13(4), 429-446. https://doi.org/10.1177/1523422311431220

Wagner, R., \& Harter, J. K. (2006). The great elements of managing. Washington, DC: The Gallup Organization. 


\section{Macrothink}

International Journal of Human Resource Studies

ISSN 2162-3058 2022, Vol. 12, No. 1

Warren, M. W. (1982). Performance management and management performance. In L. W. Frederikson (Ed.), Handbook of Organizational Behaviour Management. New York: John Wiley. 539-64.

Watson Wyatt Worldwide (2004). Performance management programs earn a failing grade. Work USA 2004: An Ongoing Study of Employee Attitudes and Opinions-PM Summary.

\section{Copyright Disclaimer}

Copyright for this article is retained by the author(s), with first publication rights granted to the journal.

This is an open-access article distributed under the terms and conditions of the Creative Commons Attribution license (http://creativecommons.org/licenses/by/4.0/). 